Religion and Gender, vol. 1, no. 1 (2011), 66-84

www.religionandgender.org

URN: NBN:NL:UI:10-1-101578

ISSN: 1878-5417

Publisher: Igitur Publishing (Utrecht)

Copyright: this work is licensed under a Creative

Commons Attribution License (3.0)

\title{
Implications of Queer Theory for the Study of Religion and Gender: Entering the Third Decade
}

\section{CLAUDIA SCHIPPERT}

\begin{abstract}
This essay explores the conceptual and contextual shifts in queer theoretical work as it is entering into its third decade of articulation. The essay reviews important recent themes in, and examines implications of, queer theoretical scholarship for the study of religion and gender. I suggest that among the implications are a more un-disciplined study of religion (and secularism) that takes seriously shifts resulting from transnational and diasporic queer scholarship, as well as shifts in conceptions of agency and resistance resulting from analyses and critique of homonormative positions, and that can critically intervene in homonationalism and Islamophobia.
\end{abstract}

\section{Keywords}

Queer theory, queer critique, homonormativity, queer religious studies, North America.

\section{Author affiliation}

Claudia Schippert is Associate Professor of Humanities and Religious Studies at the University of Central Florida in Orlando, Florida, USA. Her research is in queer theory and religion, feminist and queer ethics, religion and popular culture, as well as critical approaches to bodies and sexualities. Her current research projects 
include work in queer pedagogy, queer popular culture studies, and a project tentatively titled 'Queer Discipline'. Email: claudiaschippert@gmail.com

\section{Introduction ${ }^{1}$}

Queer theory has existed for roughly two decades and has contributed to diverse fields of inquiries in a number of academic disciplines and areas of scholarly engagement. Originally developed in the early 1990s, at the intersection of theory and activism, queer theorists intended to problematize the production of dominant and normative categories of sexuality. Drawing on Michael Warner's phrase, 'resistance to heteronormativity' served as a summarizing description for queer theoretical projects. ${ }^{2}$ Much of the work in the first decade was spent explicating how norms became networked through practices and institutions in producing and maintaining heteronormativity. While queer theorists in academic contexts intended to disrupt the reliance on identity categories that had been the foundation for a great deal of liberationist politics, some early criticism pointed to the persistent whiteness and dominant literary discourses engaged. In the study of religion and gender, liberationist approaches had figured prominently and significant debates around the importance of agency and community took place.

The shift from identity-based analysis to the queer positionality of 'resistance to heteronormativity' helpfully shifted the subject at the centre of the study of religion and gender. Whereas earlier approaches may have relied on assumed gender divisions (men's rituals, women in Judaism and so on), queer theory provided a challenge to the definitions of categories of gender and helped to disrupt existing perspectives of investigation and discover new ones. Applying the subversive intentions of queer theory to the study of religion, liberation theologians, religious studies scholars, and religious ethicists began to explore queer theory's potential in the late 1990s. Among the themes that scholars of religion have discussed are queer challenges to Christian theology, LGBT (lesbian, gay, bisexual and transgender) and queer readings of the Hebrew and Christian Scriptures,

1 The author gratefully acknowledges support received through a sabbatical leave from the College of Arts and Humanities at the University of Central Florida.

2 M. Warner (ed.), Fear of a Queer Planet: Queer Politics and Social Theory, Minneapolis: University of Minnesota Press 1993, xxvi. 
and explorations of the intersections of sexual and religious identities. ${ }^{3}$ Important extensions of liberation theology included queer theology from the margins of sexual deviance and economic exclusion; Marcella AlthausReid's work is exemplary for these developments. ${ }^{4}$ The implications of transgender and intersex identities for theology and the study of religion have more recently become important themes. ${ }^{5}$

It should be noted that, at this point of the development and dispersion of queer theoretical work in the academy, no essay can cover all of queer theory and religion. This essay's scope is limited to a primarily North American context and to religious studies as it surfaces within scholarly discussions in that geographic context. While queer studies in the North American context surely intersect with many other fields, in this essay the recently prominent contributions from and intersections with postcolonial studies are foregrounded. I argue that these recent approaches provide sets of particularly critical and productive challenges with far-reaching implications for the study of gender and religion.

In this essay I thus focus on the conceptual and contextual shifts that queer theoretical work is contributing to academic discourse. In particular, I suggest that the very discipline of religion is being challenged, certainly in the ways it has been constituted in its modern academic

3 R. E. Goss, Queering Christ: Beyond Jesus Acted Up, Cleveland: Pilgrim Press 2002; R. E. Goss and M. West (eds.), Take Back the Word: A Queer Reading of the Bible, Cleveland: Pilgrim Press 2000; D. Boyarin, D. Itzkovits, and A. Pellegrini (eds.), Queer Theory and the Jewish Question, New York: Columbia University Press 2003.

4 M. Althaus-Reid, Indecent Theology: Theological Perversions in Sex, Gender, and Politics, New York: Routledge 2001; The Queer God, New York: Routledge 2003. In Indecent Theology she argues that all theology is sexual theology and, bringing queer theory into further productive conversation with feminist materialism and liberation theology; in her subsequent study, The Queer God, she challenges the oppressive powers of heterosexual orthodoxy, whiteness, and global capitalism.

T. Sheffield, 'Performing Jesus: A Queer Counternarrative of Embodied Transgression' in Theology \& Sexuality 1:3 (2008), 233-258; S. Cornwall, Sex and the Uncertainty in the Body of Christ: Intersex Condition and Christian Theology, Sheffield: Equinox 2011. Sheffield demonstrates that 'a queer reading of the Chalcedic body, analysed alongside transgender narratives, is a site from which to construct identities of hybridity and transgression that disrupt ancient and contemporary fictive narratives of normative gender and sexuality.' Similarly, Cornwall's first full-length examination of the theological implications of physical intersex conditions and their medical treatment explores the necessary shifts in a body-focused theology when we take seriously perspectives that defy binary or complementary gendered embodiment. 
version, when we take seriously what current queer studies bring to the discussion. Likewise, what emerge as proper objects of study for (queer) scholarship on gender and religion is affected. The essay contains four sections. In the first section I ask what it means to study religion queerly and argue for studies of religion in unlikely places and with at times unlikely trajectories. Specifically exploring studies that are queering religion (and secularism), I point to examples such as the study of an organization of parodic drag performers that is (not?) religious and the study of secularism through the lenses of queer religious studies. While the discipline of religious studies has adapted queer methodologies only haltingly, these are some promising developments. I argue that in order to study religion queerly, religious studies finally need to become (more) undisciplined.

Secondly, the rising importance of transnational and diasporic queer and feminist scholarship, especially within the North American context, with which this essay is primarily concerned, is briefly reviewed and potential implications for religious studies are discussed. In the third section I explore what since Lisa Duggan coined the term has been called 'homonormativity': the emergence and analysis of a homosexual normative position that defends itself against 'queerer' others. I argue that these trends toward an idealization (or perhaps assimilation) of 'queer' are dangerously problematic - and they certainly are contrary to the nonnormative etymology and scholarly use of 'queer'. Scholars rightly call for vigilance and a shift in attention to a different conception and function of 'normativity', especially, perhaps, within queer ethics. This direction of critique within queer studies is helpful to - and needs to be considered in further development of - queer approaches to religion and gender. The fourth section focuses on a current analysis of homonationalist strategies and their connection to Islamophobia and US domestic anti-terrorism strategies. The resulting increased detention and incarceration, in the US and elsewhere, emerges as a relevant and critical topic for the queer study of religion and gender in a contemporary political context.

\section{Studying Religion Queerly}

What does it mean to study religion queerly? Applying queer theoretical approaches to/in the study of religion results in different topics that can surface as proper objects of study. It is to be expected that these topics change depending on the geographic, cultural and political context and the 
shape of studying religion queerly is thus never finally determined. As I have suggested elsewhere:

The content of a queer theoretical approach, which seeks to engage and disrupt these [heteronormative] procedures, varies depending on the shape or function normativities take in particular settings. Consequently, at the intersection with the study of religion, realms of 'appropriate' areas of study might shift and new fields can come into focus (transvestites, gay bars, and drag queens as realms for learning about the performance of sanctity, as Althaus-Reid would have it, for example). ${ }^{6}$

The history of early applications of queer theory to religious studies has been anything but straightforward. While there has been ongoing work to synthesize queer approaches to religion and gender, early anthologies like the one edited by Comstock and Henking exemplify the invocation of queer as a summarizing term for LGBT identities without much space given to queer theoretical critiques. Yet Thumma and Gray's Gay Religion gathers interesting essays that go beyond merely gay identified religion or religious practitioners. $^{7}$

In the context of theology, Loughlin recently reflected on some early queer theorists' moving away from queer terminology, because it had become too implicated in normative and identity-based strategies. He suggests that theology might be catching up a bit more slowly, which might, in turn, offer its own set of possibilities:

But the term [queer] - and its deployment - is less well known in theology, and so it is still possible that this positionality, this distancing or divergence from what is held as normative, will serve to destabilize and undo that normativity: the surety of heteropatriarchal Christianity. But in the case of theology there is something more. ${ }^{8}$

Loughlin has in mind here the specific parallel he sees between a [queer] 'identity without an essence' and what some Christian theologians - going as far back, he suggests, as Thomas Aquinas - would call 'the name of God'. Further exploring the challenging intersections of queer theory and theology in the recent anthology Queer Theology, many of the AngloAmerican contributors make the body and desire a central issue for

C. Schippert, 'Queer Theory and the Study of Religion' in Rever 5:4 (2005), 90-99.

G. D. Comstock and S. E. Henking (eds.), Que(e)ring Religion: A Critical Anthology, New York: Continuum 1997; S. Thumma and E. R. Gray (eds.), Gay Religion, Walnut Creek: AltaMira Press 2005.

8 G. Loughlin (ed.), Queer Theology: Rethinking the Western Body, Malden: Blackwell 2007, 9-10. 
reflection in Christian theology. They demonstrate, for example, that a great deal of Christian texts and traditions are significantly queerer than the development of modern Church doctrines and teachings might suggest. One goal of the ongoing development of such a queer theology, then, might be to uncover the queerness that was always already in Christianity, perhaps even at its very core. Such an argument resembles literary theorist Eve Sedgwick's earlier queer theoretical work in literary theory. ${ }^{9}$ Sedgwick had claimed that modern European and North American literature must be read from an anti-homophobic perspective in order to understand the formation of modern normatively gendered narratives. Sedgwick pointed to the frequent deployment of erotic triangles that are central to the development of (heteronormative) characters. Indeed, she argued that much of modern, presumably heterosexual, masculine identity is based on homosocial relationships. In what might constitute a parallel move, queer theologians such as David Matzko McCarthy re-read the queer desires of saints. And Tina Beattie examines the particular heterosexualization and domestication of Mary within Christian history. She suggests how a critical rereading can uncover the queerness, or non-heteronormativity, of a Christian attempt to seek immortality not through raising offspring but through eternity in Christ. ${ }^{10}$

Even when focusing on religious studies beyond theology, as I do in the remainder of this essay, the intersections of queer theory and religion have been notoriously difficult and underexplored and the study of religion seems to be adapting only haltingly and partially to contemporary developments in LGBT studies and queer theory', as Melissa Wilcox suggests in her assessment of the field of queer studies in religion. ${ }^{11}$ Nonetheless, scholars of religion and gender have much to contribute to

9 E. K. Sedgwick, Between Men: English Literature and Male Homosocial Desire, New York: Columbia University Press 1985; Epistemology of the Closet, Berkeley: University of California Press 1990.

10

Loughlin summarizes 'the undertaking of queer theology' as follows: 'to make the same different, the familiar strange, the odd wonderful; and to do so not out of perversity, but in faithfulness to the different, strange, and wonderful by which we are encountered in the story of Jesus and the body of Christ' (31). The contributors to the Queer Theology anthology vary greatly in their investment in perversity versus faithful engagement with the tradition, but taken as a whole the collection can illustrate some of the current struggles at the disciplinary intersection of queer theory and theology.

M. M. Wilcox, 'Outlaws on In-Laws? Queer Theory, LGBT Studies, and Religious Studies' in K. E. Lovaas, J. P. Elia, and G. A. Yep (eds.), LGBT Studies and Queer Theory: New Conflicts, Collaborations, and Contested Terrain, Binghamton NY: Haworth Press 2006, 73. 
queer studies - and much to further develop in applying contemporary queer theory to the study of religion. Wilcox points to the potential of 'paying close attention to the dynamics of gender and sexuality that religions hide in plain sight [...] and the roles of religion in both inscribing and challenging heteronormativity and dualistic conceptions of gender. ${ }^{12}$

Work in performance studies has been influential in the formation of queer theory from the beginning. For example, performance studies scholars like José Muñoz have shown the importance of investigating performance to glean queer strategies of resistance and disidentification, especially among queers of colour. ${ }^{13}$ Paying careful attention to queer practices and rituals from the perspective of religious studies can point those studying religion and gender in important directions of rethinking identity, agency, and resistance. In this vein, some scholars have turned to queer practices within realms that might be considered akin to or part of religion while they may not always have surfaced as legitimate areas of study within the academic discipline.

Wilcox makes the case that while the Sisters of Perpetual Indulgence are not a religious organization, they offer a rich site to rethink existing categories of 'religious', 'spiritual', and 'secular'. ${ }^{14}$ The white-faced Sisters combine Catholic imagery with drag and leather culture and offer a complex site for queer religious negotiations. As the Los Angeles house explains, they are:

an order of gay male, lesbian, bisexual, transgender, and non-gay nuns whose mission is the expiation of stigmatic guilt and the promulgation of universal joy. The same way the Catholic Church sold indulgences in the Middle Ages to forgive people their sins, the Sisters have granted the lesbian and gay community a perpetual indulgence, forgiving them of all sin and guilt often placed upon them by right-wing religious and political organizations.' The Sisters' main goals, says the Los Angeles chapter, are 'to strengthen [their] community through drag activism, by raising muchneeded funds for community charities, and by bringing about a better understanding of gay spirituality'. ${ }^{15}$

\footnotetext{
Wilcox, 'Outlaws' 93.
}

13 J. E. Muñoz, Disidentifications: Queers of Color and the Performance of Politics, Minneapolis: University of Minnesota Press 1999; Cruising Utopia: The Politics and Performance of Queer Futurity. New York: New York University Press 2009.

M. M. Wilcox, Queer Women and Religious Individualism, Bloomington: Indiana University Press 2009.

15 Wilcox, Queer Women, 77. 
Wilcox demonstrates that the distinction of compliance and resistance is complicated when the group functions for some queers 'as a central part of [their] religious and spiritual practice.'

As a parody of the Roman Catholic Church, gleefully intoning their rallying cry-'Go forth and sin some more!'-the Sisters' playful queering of religious space intersects with a searing critique. Yet as a secular organization, the Sisters become sacralized queer space when members (...) find in them a deep expression and source of spirituality. ${ }^{16}$

Taking seriously the complexity of parodic and other practices at the intersection of what is defined as 'religious' and 'secular' can afford scholars of gender and religion insights into the manipulations of norms and agency at play. At the same time, attention to the simultaneity of religious and secular significance of organizations such as the Sisters raises the related issue of rethinking the distinction between definitions of the secular and religious itself.

Within modern European and North American contexts, secularism has been viewed as the other to religion. And yet, Janet Jakobsen and Ann Pellegrini argued that the religious/secular distinction is a distinction without a difference. They explored, in Love the Sin, how specifically Protestant Christian claims have entered the legal decisions of the United States Supreme Court and other purportedly secular institutions. ${ }^{17}$ In demonstrating the religious, and specifically Protestant, basis of sexual regulation in US law, Jakobsen and Pellegrini bring sexuality and gender studies together with religious studies and ethics to bear on issues of contemporary sexual regulation. While developing a queer ethics of valuing sex differently, their work also signals another important direction of queer studies in religion, that is, the emerging work on the Christian nature of US secularism and implications for addressing secularism in critically informed ways.

In the introduction to the edited volume, Secularisms, Jakobsen and Pellegrini further describe their approach:

Our argument is not that this [modern American] secularism is really (essentially) religion in disguise, but rather that in its dominant, marketbased incarnation it constitutes a specifically Protestant form of secularism.

16 Wilcox, Queer Women, 129 and 187.

17 J. R. Jakobsen and A. Pellegrini, 'Getting Religion' in E. A. Castelli (ed.), Women, Gender, and Religion: A Reader, New York: Palgrave 2001, 518-527. 
The claim of the secularization narrative is that the secularism that developed from these European and Christian origins is, in fact, universal and fully separate from Christianity. As a number of critics have now argued, however, and as we shall see [in the anthology], there are reasons to doubt that claim. Secularism remains tied to a particular religion, just as the secular calendar remains tied to Christianity. ${ }^{18}$

Many contributions to Secularisms demonstrate that the very categories of 'secular' and 'religious' need to be rethought, including the specific relationships of secularisms to religions other than Christianity in other parts of the world. ${ }^{19}$ I suggest that one particularly timely project within queer studies in religion that is always also implicating the study of gender, is related to the undoing, or recalibrating, of binary terminology of religion and secularism 'so as to open new configurations in the political debates structured by them. ${ }^{20}$

When approaching religion queerly, then, we can no longer simply 'add' queer identities to an 'inclusive' liberationist agenda (not that there is anything simple about liberation). The implications of the challenges and rethinking of the field of religion indicate that what is being studied as the discipline of religion is shifting to focus on previously excluded topics. Studying religion queerly can be, and perhaps will need to be, (more) undisciplined.

\section{Transnational and Diasporic Queer Scholarship}

A great deal of scholarly activity in the second decade of queer theoretical work in North America concerned the expansion of queer theoretical approaches beyond the initial fields of literary and film studies. In this context, political and social issues have moved further to the centre of investigation. What 'counts' as a queer topic has shifted to include questions that no longer add as an afterthought but rather centrally explore race and ethnicity, and that approach issues of gender and sexual identity from within diasporic or transnational contexts. While some might argue that this is a specifically North American preoccupation, I would assert that the material circumstances of diasporic or migrant bodies and

\footnotetext{
18 J. R. Jakobsen and A. Pellegrini (eds.), Secularisms, Durham: Duke University Press 2008, 3.

19 For example Najmabadi's essay on Muslim feminism in Iran or Rajan's discussion of Indian feminist concerns about the privatization of religion and related proposals of a reconfiguring of public relations between religious and secular discourses in India. 
communities emerge as an increasingly global phenomenon with the implicit need for critical engagement in local or specific national political strategies. ${ }^{21}$ The negotiations of material circumstances tend to occur in connection with religious practices and identities and thus offer a rich field for ongoing explorations of religion and gender. ${ }^{22}$

Theoretical approaches to transnational sexualities and queer diasporic identities have challenged queer theorists to address identities, community and consumption practices, and the workings of kinship and family practices in more complex configurations. No longer is the white gay Western (Christian/secular) man the assumed author, audience, or object of study within queer theoretical texts. Prolific and promising work has been forged within queer South Asian studies. For example Gayatri Gopinath examines the ways in which discourses of sexuality are inextricable from prior and continuing histories of colonialism, nationalism, racialization, and migration. Martin Manalansan's ethnography of immigrant Filipino gay men in New York City carefully traces how their identity develops not necessarily along the same lines as queer modernity or citizenship narratives would suggest. ${ }^{23}$ In these areas, the relevance of religion in the creation and maintenance, but also the disruption of normative and queer configurations, is not to be underestimated, but has not yet been fully explored.

21 See for example A. Cruz-Malave and M. F. Manalansan (eds), Queer Globalizations: Citizenship and the Afterlife of Colonialism, New York: New York University Press 2002. For example, several essays in the important 2005 special issue of Social Text, 'What is Queer About Queer Studies Now?', discuss the by now infamous 'Queer Shame' conference in Michigan in 2003, specifically exploring how the almost exclusive whiteness of the invited speakers became a visible marker for a problem increasingly addressed in terms of the normativity of whiteness, maleness, and North American cultural identity within academic queer studies, or what Perez argues is a 'resistance in white establishmentarian queer theory to thinking race critically.' H. Perez, 'You Can Have My Brown Body and Eat It, Too!' in D. L. Eng, J. Halberstam, and J. E. Muñoz (eds.), What's Queer About Queer Studies Now? Social Text 84-85, 23:3-4 (2005), 171191. Also see J. Halberstam, 'Shame and White Gay Masculinity' in Social Text 84-85, 23:3-4 (2005), 219-234. The Social Text special issue marks a collection of work by younger scholars who have since developed diverse approaches within queer studies. Their work's potential influence within the study of religion and gender is still not fully explored, but many significant points of connection exist.

G. Gopinath, Impossible Desires: Queer Diasporas and South Asian Public Cultures, Durham: Duke University Press 2005. M. Manalansan, Global Divas: Filipino Gay Men in the Diaspora. Durham: Duke University Press 2003. 
One example of specific attention to the complexity of religious, sexual/gender and national identity negotiations is found in Salvador VidalOrtiz's work on the syncretic Santería. ${ }^{24}$ He demonstrates that when queer practitioners attempted to distance themselves from certain constructions of gay identity that would be recognizable to mainstream US culture, this break from gay identification should not be viewed simply as a result of homophobia. Rather, he suggests,

[W] hat is seen as homophobia by some is actually a negotiation of a relationship to 'Americanness,' a resistance to constructs of gayness, and a rejection of a culture of ethnicity-based consumerism and identification. Because the sexual identity formation literature has not given much room for anything outside of a gay identification - the alternative most often is adherence to a homophobic culture ... - ruptures within sexual identities that do not belong to either of those, or to both simultaneously, are twice unintelligible. ${ }^{25}$

The emerging body of queer ethnic and diasporic scholarship challenges many assumptions in conventional - including queer conventional scholarship regarding kinship or same sex desire. It is producing new perspectives and a reordering of issues concerning identities, nationalism, communities, and material practices. Scholars of religion and gender have a rich emerging body of critical work to engage - to which scholarship attentive to gendered rituals or transformative practices can make important contributions.

The analysis of gender and religion in popular culture in particular could bring recent queer studies into helpful conversations with religious studies. For example, BUBOT NIHAR (Paper Dolls), a documentary by Israeli filmmaker Tomer Heymann, chronicles the lives of several transgender Filipino migrant workers in Israel, who are also performers in a weekly drag show, called Paper Dolls, for the Filipino queer community in Tel Aviv. ${ }^{26}$ Filling the positions taken by Palestinian workers before the second Intifada in 2000, most work as health caretakers for elderly Orthodox Jewish Israelis and are precariously positioned within Israeli society, because they are ineligible for citizenship and their work visas are tied to their employment. The documentary traces several individuals'

\footnotetext{
24 S. Vidal-Ortiz, 'Sexuality and Gender in Santería: LGBT Identities at the Crossroad of Santería Religious Practices and Beliefs' in S. Thumma and E. R. Gray (eds.), Gay Religion, Walnut Creek: Altamira Press 2005, 115-137.

Bubot Niyar (Paper Dolls). Dir. T. Heymann 2006. Prod. Claudius Films.
} 
transgender identities as they are differently defined vis-à-vis dominant norms both of Israeli society or larger 'Western' normative discourse, and vis-à-vis the pre-migration Filipino context. Allan Isaac argues that Heymann's depiction of the rituals and communities invokes 'multiple sets of mediations in gender and national belonging, but gestures towards a different sense of pleasure, danger and beauty/byuti, a concept elaborated on by Martin Manalansan in Global Divas. ${ }^{27}$ Additionally, I would note, we might find rich layers of signification that relate to gender and religion, such as the question of how Jewish and Catholic practices of kinship intersect with narratives of national belonging that support and/or undo specific gendered roles.

In addition to a shift away from, or beyond, disciplinary (or modern discursive) conceptions of religion as a field of study, studying religion from within transnational frameworks challenges normative assumptions of race, cultural and religious location and identity. Geography and economy matter, that is to say materially register and influence lived reality, in ways that need to be more fully explored within a queer study of religion and gender, or a study of religion that is done queerly.

\section{Homonormativity and Critique of Queer Ideals}

It was within the context of an emerging 'responsible' homonormative position, marked by attacks on promiscuity and other deviant sexual practices from within the gay community, that 'a new strain of gay moralism' developed. It began to advocate for rights in increasingly narrow private realms, almost exclusively organized around the issues of same sex marriage and gay participation in the military. ${ }^{28}$ Lisa Duggan first used the term 'the new homonormativity' in an article describing the sexual politics of neoliberal conservatism, offering an extended critique of approaches such as conservative American gay journalist Andrew Sullivan's aim to establish the 'normality' of the 'good' and responsible gay subject along similar lines to the ones defining the heteronormative subject. In other words, establishing the subject's normality and value by distinguishing itself from and vilifying as deviant the other, who is often racialized, class-

27 A. Isaac, 'Filipino Visuality and Other Minor Diversions', unpublished paper presented at Affective Tendencies: Bodies, Pleasures, Sexualities, Rutgers University, 9 October 2010.

L. Duggan, 'The New Homonormativity: The Sexual Politics of Neoliberalism' in R. Castronovo and D. D. Nelson (eds.), Materializing Democracy: Toward a Revitalized Cultural Politics, Durham: Duke University Press 2002, 182. 
marked, sexually deviant, and/or unpatriotic. This new homonormativity, Duggan suggests, 'is a politics that does not contest dominant heteronormative assumptions and institutions but upholds and sustains them while promising the possibility of a demobilized gay constituency and a privatized, depoliticized gay culture anchored in domesticity and consumption. $^{29}$

Attention to the operation of norms within queer approaches had been important in earlier queer theoretical work in religion, for example Jakobsen and Pellegrini's Love the Sin. ${ }^{30}$ More recently, the seemingly ubiquitous definition of queer as 'resistance to normativity' has been critically evaluated and the implicit operations of norms within queer approaches themselves have found closer scrutiny.

In particular, transgressiveness or resistance that is understood as 'freedom from norms' had become something like a queer ideal which, problematically, is too easily connected to liberal individualism and conceptions of a humanist subject. Such a queer ideal also often relies on an emancipatory or progressive narrative that would require the ideal queer to emancipate himself (sic!) from practices and spaces that are viewed as normative, or from communities and practices that are 'not quite as free yet'. Such an ideal(ized) queer subject often relies on a stylized adherence to capitalist consumer choices that imagines escape from the bonds of family and other normative spaces as ideally queer. Conversely, such an approach often considers all practices and persons who remain 'caught' within normative spaces as unable to enact resistance or queer agency. As Jasbir Puar writes: 'In this problematic definition of queerness, individual agency is legible only as resistance to norms rather than complicity with them, thus equating resistance and agency. ${ }^{31}$ I want to suggest that recent work by Saba Mahmood can provide important

29 Duggan, 'The New Homonormativity', 179.

30 J. R. Jakobsen and A. Pellegrini, Love the Sin: Sexual Regulation and the Limits of Religious Tolerance, Boston: Beacon Press 2004. Also see J. R. Jakobsen, 'Queer Is? Queer Does?: Normativity and Resistance' in GLQ: A Journal of Lesbian and Gay Studies, 4:4 (1998), 551-536; C. Schippert, 'Containing Uncertainty: Sexual Values and Citizenship' in K. E. Lovaas, J. P. Elia, and G. A. Yep (eds.), LGBT Studies and Queer Theory: New Conflicts, Collaborations, and Contested Terrain, Binghamton NY: Haworth Press 2006, 285-307.

31 J. K. Puar, Terrorist Assemblages: Homonationalism in Queer Times, Durham: Duke University Press 2007, 23. 
perspectives by studying feminist and queer agency that supports and consolidates norms. ${ }^{32}$

Mahmood's ethnography of a women's piety movement that is part of the larger Islamist movement in Egypt demonstrates how ethics and politics are connected in the moral reform movement whose orthodox practices tend to be viewed as irrelevant or of no great significance to political considerations. In her careful ethnographic study, Mahmood demonstrates that the women's practices accomplish negotiations with various levels of authority, even though many of their activities might not be noticed by a typical feminist postcolonial observer. Mahmood confronts the difficulties that a great deal of feminist analysis has with the dilemma of 'women's active support for socioreligious movements that sustain principles of female subordination. ${ }^{33}$ As her study shows, rather than avoiding such case studies by declaring the groups to suffer from 'false consciousness', a more nuanced investigation of agency can shed light on complex negotiations that can queer/disrupt/shift the modern Western white conception of agency (and, by extension, also a queer insistence on transgression of norms as the sine qua non of queer agency). Such an argument is especially important in the study of Muslim communities and practices, as they continue to be perceived in a steadfastly 'backwards' manner in the mainstream Western (including feminist and queer scholarly) imagination.

Mahmood shifts from an individual focus on agency to one that accounts for complexity in the networks of power and authority that give rise to the subject. She is particularly critical of existing feminist scholarly work on resistance that is preoccupied with finding resistance and subversion of existing norms and as a result, at times, remains blind to the productive practices that might draw on particular norms and can nonetheless result in shifted configurations enabling life.

I believe it is critical that we ask whether it is even possible to identify a universal category of acts-such as those of resistance-outside of the ethical and political conditions within which such acts acquire their particular meaning. Equally important is the question that follows: does the category of resistance impose a teleology of progressive politics on the

32 S. Mahmood, Politics of Piety: The Islamic Revival and the Feminist Subject, Princeton: Princeton University Press 2005. Also see S. Ahmed, The Cultural Politics of Emotion, New York: Routledge 2004; Queer Phenomenology: Orientations, Objects, Others, Durham: Duke University Press 2006. 
analytics of power-a teleology that makes it hard for us to see and understand forms of being and action that are not necessarily encapsulated by the narrative of subversion and reinscription of norms? ${ }^{34}$

Detaching the notion of agency from the goals of progressive politics, Mahmood deploys a Foucauldian approach to ethical practices in describing how norms of modesty and piety are lived within the movements she studies. She points out that the most interesting features of this debate lie not so much in whether the norm of modesty is subverted or enacted, but in the radically different ways in which the norm is supposed to be lived and inhabited. ${ }^{35}$ Shifting the debate thus can also open up new ways of understanding how norms and agency interact. Agency on the part of the women participating in the mosque movement in Egypt is thus delinked from specific liberatory feminist ideals or concepts of agency tied to progressive politics. Nonetheless, when observed closely, the women's practices have specific consequences in the configurations of power. For example in the realm of secular-liberal sociability and secularliberal governance, even though these results may not map exactly on the intentions of the pietist movement.

What emerges in Politics of Piety is not a series of typical activist or progressive practices, but ' $[t]$ he political efficacy of these movements is (...) a function of the work they perform in the ethical realm-those strategies of cultivation through which embodied attachments to historically specific forms of truth come to be forged. ${ }^{36}$ Earlier Mahmood had pointed out that one 'might say that the political agenda of the mosque movement (the 'resistance' it poses to secularization) is a contingent and unanticipated consequence of the effects its ethical practices have produced in the social field. ${ }^{37} \quad$ Mahmood intervenes helpfully in feminist approaches that would too easily presuppose the kind of agency they wish to discover or evaluate in progressive and women's movements. She aims at recentering the relevance of 'resistance' and the category of agency away from a prediscursive voluntary subject to one emerging as effect of bodily and religious practices. In her methodologically useful reflections on the ethics of critique, Mahmood further demonstrates how learning about the mosque movement required bracketing of sentiments already formed in relation to religious and socially conservative movements, in order to

\footnotetext{
Mahmood, Politics of Piety, 9.

Mahmood, Politics of Piety, 23-4.

Mahmood, Politics of Piety, 35.

Mahmood, Politics of Piety, 34-35.
} 
unlearn our assumptions about neoliberal movements and to hold open 'the tension between the prescriptive and analytical aspects of the feminist project. $^{38}$

While Politics of Piety engages primarily feminist and postcolonial studies, I suggest that Mahmood's approach is instructive to queer scholarship on gender and religion in successfully decentering the (often Western white male Christian) assumption of resistance or transgressiveness that the 'ideal queer' too often seems to posit. Further studies that explore queerness with regard to religion and gender should address the implications of the problems that are posed when a notion of queerness as transgression must always rely on a notion of deviance.

\section{Homonormativity, Homonationalism, Terrorism, and Islamophobia}

While I have remarked above on the significant implications of queer theory in the expansion of 'proper objects of study' within the academic study of religion and gender, I also want to suggest that the critique of homonormative logics, discussed in the previous section, has been helpfully applied to many areas beyond what might appear to be obvious 'queer areas of study' concerning homosexual or queer sexual identity. Indeed, for many years students of queer theory were puzzled by questions such as 'what does a critique of the US war in Iraq have to do with queer theory?' While more traditional materialist or other radical political philosophies surely had much to contribute to such debates, the contributions from a queer theory and a queer religion perspective had been less developed. I suggest that as we are entering a third decade of queer theory, the particularly pressing issue, not only in the North American context but in other parts of the world as well, of domestic policing and increases in incarceration of immigrants as well as religiously and racially non-normative bodies has become a central concern to queer theoretical work. A critical approach to the recruitment of homonormative logics in the service of anti-terrorism and the related vilification of Islam must include the recruitment of queerness in the specific religious-political issue of Islamophobia.

As Anna Agathangelou and others point out, the basis for the decriminalization of sodomy (Lawrence and Garner vs State of Texas) and the demand for recognition of same sex marriage 'is a highly privatized, monogamous, and whitened docile subjectivity that has been

38

Mahmood, Politics of Piety, 39. 
decriminalized and ostensibly invited into the doors of U.S. national belonging through recent shifts in the gendered and sexual order. ${ }^{39}$ The neoliberal logics that affirm private rights and security are closely connected to homonormative strategies such as those analysed by Agathangelou in the Human Right Campaign's advocacy for 'the good queer citizen [to gain] entrance into the nation through the displacement and explicit effacement of racial, sexual, and class antagonism and inequities. $^{\prime 40}$

An argument important for contemporary queer theoretical work to engage is that the gay rights recently gained, as well as the increasingly privatized freedoms for queer subjects, coincide with the loss of rights of (more) deviant and non-national (non)subjects. That these non-citizen bodies and the (specifically black) bodies within the US are relegated into the backdrop becomes hardly noticeable, and the civic death these bodies face becomes more thoroughly naturalized as a result of the gains in, and privatization of, the queer subject position.

These approaches have not yet been fully taken up in religious studies scholarship, but offer important and provocative challenges to the study of religion and gender, especially as it relates to contemporary cultural and political discourse. One of the most readily visible sites revolves around Islamophobia.

In the US American context, over the past ten years, Islam has been portrayed as un-American or even anti-American. This is of course not an entirely new development, as the liberal heritage of toleration always was complicatedly connected to the toleration of religiously defined others by the Christian dominant state. Nonetheless, the vilification of Islam has become especially important to analyse from a queer theoretical perspective in its imbrications with homonormative and homonational strategies. $^{41}$

The recruitment of Islam as a 'queer' deviant and backward monster in order to create a good and neutral modern Western (but, in the US, also always Christian) subject position needs to be further analysed

39 A. M. Agathangelou, M. D. Bassichis, and T. L. Spira, 'Intimate Investments: Homonormativity, Global Lockdown, and the Seduction of Empire' in Radical History Review 100 (2008), 124.

40 Agathangelou et al., 'Intimate Investments', 124.

41 It should be noted that Islamophobia is not unique to the US. Swiss bans on minarets or French prohibitions against religious dress draw on similar tropes, and Puar discusses situations in the Netherlands and Britain as well in Terrorist Assemblages. 
with particular attention to the significance of gender and sexuality within religion (and also the recruitment of religious or Protestant Christian norms in the definition of gender and sexuality). The reassertion of Christian positions as the unmarked norm ${ }^{42}$ and the positioning of Muslims as unAmerican (and thus subjects of profiling or detention or legitimate objects of violence) depends in many cases on their association with nonnormative sexuality. This is not to say that all Muslims are claimed to be homosexuals. As Ann Pellegrini points out, '[t]o be clear, it is less that Muslims are imagined to be homosexual; in fact, one of the 'proofs' that Muslims are not yet ready for civilizational prime time is that they are antihomosexual and anti-woman. ${ }^{43}$ Indeed, the image of a perversely backwards Islam is recruited in order to portray Christianity and 'the West' as innocent of sexism or homophobia and to thus make 'understandable' and normalize the religiously-based racist sentiments that have contributed to the anti-Muslim feelings and policies. ${ }^{44}$

The promotion of discourses of 'security' rely on affective economies that perceive a great threat that legitimizes the increased policing and containment of those marked as terrorist threats or criminals. At the centre of several critical analyses of homonormativity and homonationalism is increasing attention to these 'affective economies' that support the appeals to normative national belonging and the containment of threats in the spreading institutions of the carceral state and Empire. ${ }^{45}$ What has been labelled 'the affective turn' in literary, cultural, and queer studies might thus promisingly contribute to queer expansions of gender theory. Especially in the realm of ethics, these approaches offer a rich field for further scholarly work on the role of religion.

\section{Conclusion}

Queer has become 'mainstreamed' in the first two decades of queer theory's development, mostly in its meaning as a summarizing identity term, even when it has not always been inclusive of lesbian, bisexual, or transgender identities. Nonetheless, queerness has been increasingly well http://hemisphericinstitute.org/devotion/2010/10/snl-gay-weddings-at-ground-zeromosque, accessed November 30, 2010. See also J. K. Puar and A. Rai, 'Monster, Terrorist, Fag: The War on Terrorism and the Production of Docile Patriots' in Social Text 72, 20:3 (2002), 117-148. Agathangelou et al., 'Intimate Investments', 122.
} 
integrated into North American popular culture (from TV shows such as Queer Eye for the Straight Guy to an increasingly celebrated queer culture of consumption). In the process much of the critical and activist potential has been lost. As I have pointed out in this essay, the emergence of a 'normative' gay subject has become an important scholarly concern within current US queer scholarship. As sodomy was decriminalized in US law, what appears as a 'queer' political agenda seems to focus on increasingly private rights claims: mainstreamed and normative gay and lesbian subjects fight for their 'rights', often at the expense of the vilification and continued criminalization of people of colour and those sexually or religiously othered. This has been a troubling development. At the current beginning of a third decade of queer theoretical scholarship, queer support of neo-liberalism and other effects of homo-normativity and homonationalism thus emerge as central concerns to be further explored.

As we are entering the third decade of academic queer studies, then, we are faced with new challenges and new sets of conceptual tools to tackle these. Emerging work in queer studies continues to foreground the challenges in rethinking categories of bodily identity, while necessarily at times reframing the very terms of the debate. In the process we are also continuously posing important questions for the very constitution of the study of religion and gender. 